
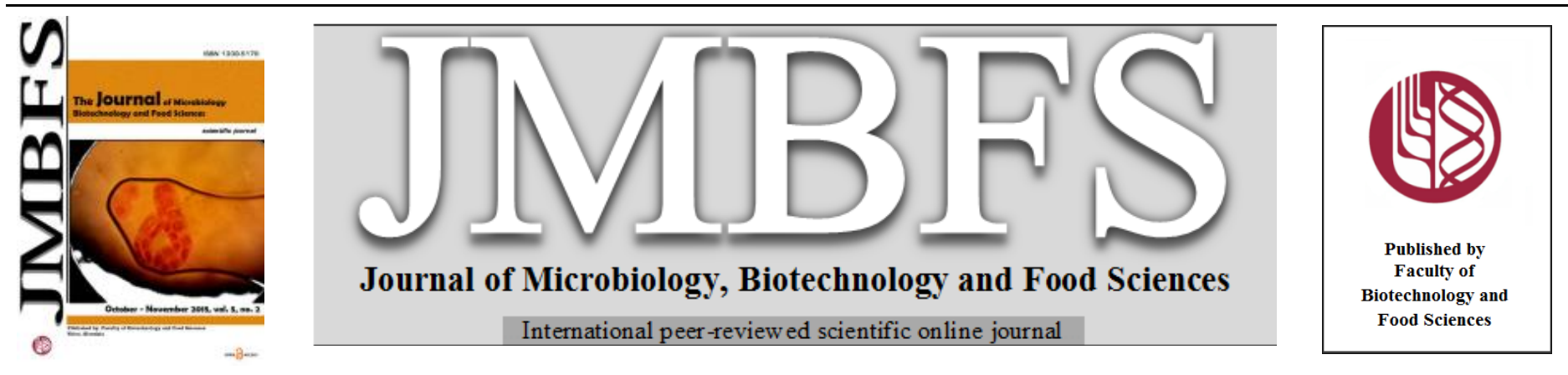

\title{
EVALUATION OF A LOOP-MEDIATED ISOTHERMAL AMPLIFICATION (LAMP) ASSAY FOR THE DETECTION OF VIRUSES IN READY-TO-EAT FOODS
}

\author{
Angeliki Birmpa, Konstantinos Kalogeropoulos, Petros Kokkinos and Apostolos Vantarakis*
}

$\operatorname{Address}(e s)$ :

Environmental Microbiology Unit, Department of Public Health, Medical School, University of Patras, 26504, Greece.

*Corresponding author: avanta@upatras.gr

doi: 10.15414/jmbfs.2015.5.2.132-135

\section{ARTICLE INFO}

Received 20. 5. 2015

Revised 22. 6. 2015

Accepted 30. 6. 2015

Published 1. 10. 2015

Regular article open $\partial$ access

\begin{abstract}
The ability of viruses to persist in the environment and on fresh produce, as well as their low infectious doses, allows even a small amount of contamination to cause foodborne viral outbreaks. Human Adenoviruses (hAdVs) of subgroup F (enteric serotypes 40 and 41) are known to be associated with 5-20\% worldwide of acute gastroenteritis cases among infants and young children. The present study aimed to evaluate a simple and cost-effective, one-step, single-tube adenovirus type 40/41 specific loop-mediated isothermal amplification (LAMP) assay for the detection of hAdV40/41 DNA in a series of ready-to-eat food samples (strawberries, sour cherries, lettuce, cherry tomatoes and green onions). No LAMP assay has previously been reported for the detection of these virus types in food samples. Results were obtained within $60 \mathrm{~min}$, under isothermal conditions at $69^{\circ} \mathrm{C}$. After amplification, the products were detected either by observing a ladder pattern following gel electrophoresis, or a color change with the addition of SYBR Green I to the reaction tube. The limits of detection of hAdV40/41 in food samples were found to be >30 GCs per reaction, when a nucleic acids extraction step was included in the analysis. A $1 \log$ higher (>100 GCs/reaction) detection limit was found for lettuce, cherry tomatoes and green onions, without a nucleic acids extraction step included before the isothermal amplification. The LAMP assay for the virological analysis of food samples is expected to provide a robust, innovative, powerful, cheap and fast monitoring tool, without the need of sophisticated equipment, which will be available for food safety testing by the food industry and the public food health authorities.
\end{abstract}

Keywords: Loop-mediated isothermal amplification (LAMP), ready-to-eat food matrices, human adenoviruses 40/41, molecular detection, food safety

\section{INTRODUCTION}

Ready-to-eat (RTE) fruits and vegetables are considered important components of a healthy and balanced diet and recognized as an important source of nutrients for humans (Meng and Gerba, 1996, Nuanualsuwan and Oliver, 2003a). It is well known that food handlers with poor personal hygiene play an important role in contaminating fresh products (D'Souza et al., 2006). The pathogens associated with environmental transmission routes, through water and food, include a wide diversity of bacteria, protozoa, as well as viruses, such as Norovirus (NoV), hepatitis A virus (HAV), hepatitis E virus (HEV) and adenoviruses (AdV). As a consequence, the use of indicator viruses is important for investigating food safety and quality (Kokkinos $\boldsymbol{e t}$ al., 2012). There is no strict evidence indicating which stage of the food production process is the most vulnerable for virus contamination. However, in the majority of contamination cases, fresh produce becomes contaminated on the farm during growing or harvesting (Heaton and Jones, 2008, Kokkinos et al., 2012). Recent foodborne outbreaks in Europe have been caused by Noroviruses present in lettuce (Feng $\boldsymbol{e t}$ al., 2011) or HAV in semidried tomatoes (Gogate, 2007). There is a need to provide rapid, sensitive, and easy screening for pathogen detection in food companies.

Although the majority of adenoviruses cause respiratory tract diseases, some of them are associated with gastroenteritis (Van $\boldsymbol{e t}$ al., 1992). It is estimated that more than $90 \%$ of the human population is seropositive for different types of adenoviruses (Fong et al., 2010). HAdVs species $F$ types 40 and 41 are enteric pathogens which are associated with 5-20\% of acute gastroenteritis cases among infants and young children (Haramoto et al., 2007, Bányai et al., 2009, Haramoto et al., 2010, Sdiri-Loulizi et al., 2009, Lee et al., 2012, RodríguezLázaro et al., 2012).

In 2000, Notomi et al. developed a novel nucleic acid amplification method, designated loop-mediated isothermal amplification (LAMP). This novel assay is advantageous since it has high specificity, sensitivity, low cost and it can be used as an easy diagnostic tool without the need of sophisticated equipment, by the food industry and the Public health authorities (Notomi et al., 2000).
The aim of the present study was the evaluation of a simple, cost-effective, onestep, single-tube adenovirus types 40/41 specific loop-mediated isothermal amplification (LAMP) assay, which has been recently published by our group (Ziros et al., 2015), for the detection of hAdV40/41 in a series of fresh ready-toeat (RTE) food samples. It is the first time that a LAMP assay is reported for the detection of these virus types in two main categories of RTE matrices (vegetables and soft fruits).

\section{MATERIAL AND METHODS}

\section{Food samples collection and processing}

Five (5) different food samples, were purchased from a local supermarket (Patras, Greece) the day of the experiment, and stored under refrigerated conditions $\left(4^{\circ} \mathrm{C}\right)$ until the time of the experiment. Specifically, fresh ready-to-eat products, such as romaine lettuce (Lactuca sativa L. var. longifolia), green onions (Allium spp), cherry tomatoes (Solanum lycopersicum var. cerasiforme), strawberries (Fragaria x ananassa), and sour berries (Prunus cerasus), were used for the specificity and evaluation tests of the developed LAMP assay.

\section{Sample inoculation-Viral attachment}

All food samples were rinsed with sterile water to remove some of the natural flora or impurities before treatment. For the inoculation of the samples of RTE products, a spot-inoculation method was applied to inoculate the hAdVs on their surface. Briefly, $10 \mu \mathrm{L}$ (5 drops) of AdV40/41, corresponding to concentrations of $10^{4} \mathrm{GCs} / 10 \mu \mathrm{l}, 10^{3} \mathrm{GCs} / 10 \mu \mathrm{l}, 10^{2} \mathrm{GCs} / 10 \mu \mathrm{l}, 10^{1} \mathrm{GCs} / 10 \mu \mathrm{l}, 10^{0} \mathrm{GCs} / 10 \mu \mathrm{l}$ (which were determined by quantitative QPCR) were spotted with a micropipette on 5 different areas of the surface of each food sample weighing 25g. After spiking, the samples were dried in a class II biosafety cabinet (Cytair 155, FluFrance), for 1 hour at $22 \pm 2^{\circ} \mathrm{C}$, to allow viral attachment. 


\section{Recovery of viruses from fresh produce surfaces}

The sample was processed by the method of Dubois $\boldsymbol{e t}$ al. (2006), as described by Kokkinos et al., (2012). The spiked food samples were diluted in $40 \mathrm{ml}$ TGBE (Tris Glycine 1\% Beef Extract Buffer) (Sigma-Aldrich) solution and then the $\mathrm{pH}$ was adjusted to 7.2. At this stage, the food samples were characterized as nonextracted and were used for the subsequent virological analysis by the LAMP assay. Alternaltively, the final pellet was compacted by centrifugation at $10,000 \mathrm{x}$ $\mathrm{g}$ for $5 \mathrm{~min}$, at $4^{\circ} \mathrm{C}$, before suspension in PBS (Invitrogen) and chloroform:butanol. Finally, the aqueous phase was transferred to a clean tube and stored at $-20^{\circ} \mathrm{C}$ until nucleic acids extraction.

\section{Nucleic Acids Extraction}

Nucleic acids (NA) from viral concentrates of fresh products were extracted using a NucliSENS miniMAG kit (bioMerieux, France), according to previous published protocols (Kokkinos et al., 2012). A negative control was included in all the nucleic acid extraction procedures. Finally, the NA eluates $(100 \mu \mathrm{l})$ were stored at $-70^{\circ} \mathrm{C}$, until used. The food samples at this stage were characterized as extracted samples and were used for the subsequent LAMP assay.

\section{Accreditation}

The Environmental Microbiology Unit (EMU) is an accredited laboratory for the virological analysis of food and environmental samples according to ISO 17025 (ESYD 550-2).

\section{LAMP Assay}

The LAMP assay was conducted in a total volume of $20 \mu \mathrm{l}$ consisting of isothermal Master Mix (ISO-001tin Isothermal Mastermix, OptiGene, UK) $(12 \mu \mathrm{l})$, the set of six primers (outer, inner, and loop primers), and target DNA $(2 \mu \mathrm{l})$. As described previously, samples were analyzed by LAMP, with and without prior nucleic acid extraction. All experiments were carried out in triplicates, and each analysis was performed at least in duplicate. The sequences of the oligonucleotide primers, the thermal profile and the optimal conditions of the LAMP assay were previously described by Ziros $\boldsymbol{e t}$ al., 2015. The primers were high-performance liquid chromatography-purified. Positive and negative controls were included in each run. Aliquots of $10 \mu \mathrm{l}$ of LAMP products were electrophoresed on $2 \%$ agarose gels and were visualized by ethidium bromide (Sigma) staining with UV light transillumination. The amplified products were also detected by adding $1 \mu \mathrm{l}$ of 1,000 X SYBR green dye to each reaction tube After incubation for $15 \mathrm{~min}$ in the dark at room temperature, a yellowish green colour indicated a positive reaction, while a reddish orange (the colour of the unbound dye) indicated a negative reaction. The colour change in the reaction tubes was examined under UV light conditions.

\section{Quantitative real-time PCR (RT-QPCR)}

For hAdV40/41 quantification, a previously described qPCR assay was performed, as described by Hernroth $\boldsymbol{e t}$ al., (2002). The assay targeted the conserved region of the hexon gene, and was performed using TaqMan Universal PCR Master Mix (Applied Biosystems). All samples were tested in duplicate (two neat and two 10 -fold diluted), in a total volume of $25 \mu \mathrm{l}(10 \mu \mathrm{l}$ sample). For each plate, the genome copies $(\mathrm{GC} / \mathrm{ml})$ were measured.

\section{Prevention of PCR carryover contamination.}

To avoid any LAMP carryover contamination strict laboratory practices were followed throughout the experimental procedure. The pre-LAMP manipulations (DNA isolation and LAMP set-up) were performed in a clean room that was isolated from the LAMP PCR machine and the post-LAMP processing area Negative controls were run with all assays, and no indications of contamination were detected. Especially, attention was paid when the caps of the used reaction tubes were opened for the addition of SYBR green dye or subsequent electrophoresis.

\section{Specificity and sensitivity of the LAMP assay}

The specificity and sensitivity of the developed LAMP assay have been previously evaluated by Ziros et al. (2015). Moreover, the specificity of the developed LAMP assay in real-world situations was evaluated in the context of the present study by analysing different food matrices, after inoculation of non hAdV40/41 DNA (hAdV35; porcine adenovirus-pAdV, Salmonella spp, Listeria monocytogenes). In addition, ten-fold dilutions of hAdV40/41, which were previously quantified by QPCR, were inoculated in food samples to determine the sensitivity of the assay for food analysis.Finally, for measuring the limit of detection (LOD) of the LAMP assay, food samples were tested in triplicate and the lowest concentration of genome copies (GCs) was taken as the limit when all of the triplicate samples were positive.

\section{RESULTS AND DISCUSSION}

\section{LAMP specificity}

The specific isothermal amplification of the DNA of hAdV40/41 strains on food samples generated ladder-like pattern bands on agarose gel. No amplification was observed in LAMP reactions without template DNA (negative control) and in the control reactions with non hAdV40/41 DNA. LAMP assay successfully detected AdV40/41 in food samples within $60 \mathrm{~min}$. There was no difference between the LAMP results detected by agarose gel electrophoresis of LAMP products or visual detection of LAMP products after SYBR Green addition and observation under UV light (Figure 1).

\section{LAMP sensitivity}

Ten-fold dilutions of $10^{0}$ to $10^{4} \mathrm{GCs}$ of hAdV40/41 in the selected food matrices were used for the sensitivity assays. The analytical sensitivity of the LAMP assay for extracted food samples was estimated to be higher than $30 \mathrm{GCs} /$ reaction (Figure 2), which is in accordance with the study of Ziros et al. (2015). Whereas, the analytical sensitivity for non-extracted food samples was found higher than $200 \mathrm{GCs} /$ reaction compared to extracted food samples.

\section{Rapid and Specific Detection of hAdV40/41 in RTE food samples}

For every batch of the food samples tested, a control sample (non-inoculated with virus) was tested to investigate any potential initial contamination. Additionally, these Assays (LAMP) are per definition very specific to the microbial targets (Kokkinos et al., 2014; Ziros et al., 2015) and it is well known that they are very robust to non-target nucleic acids presence (Francois et al., 2011).

When the LAMP assay was performed with extracted samples, all food samples (strawberries, sour cherries, lettuce, green onions, cherry tomatoes) exhibited an amplification (positive LAMP assay). When the LAMP assay was performed without prior nucleic acids extraction, the target hAdV41 was detected only in lettuce, cherry tomatoes and green onions (Figure 1). The sensitivity was estimated to be higher (able to detect up to $10^{1} \mathrm{GCs} /$ reaction) for extracted food samples (lettuce, cherry tomatoes, and green onions), and lower (up to $10^{2}$ GCs/reaction) for non extracted samples (Figure 2).
$A$

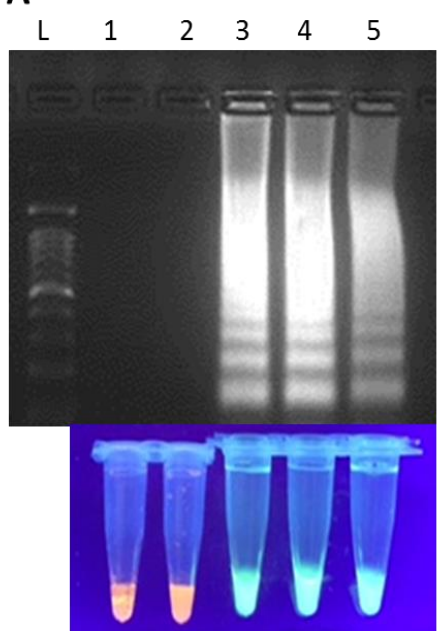

B

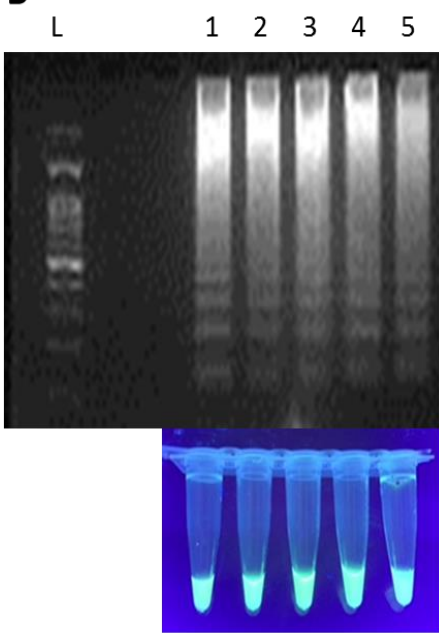

Figure 1 A: LAMP amplicons from RTE food samples, without prior nucleic acids extraction (left), and B: LAMP amplicons from RTE food samples with nucleic acids extraction (right) (Lane L: 100bp DNA ladder, Lane 1: strawberries (A: negative left, B: positive right), Lane 2: sour cherries sample (A: negative left, B: positive right), Lane 3: lettuce (A: positive B: left :positive right), Lane 4 cherry tomatoes (A: positive left, B: positive right), Lane 5: green onions (A: positive left, B: positive right) 


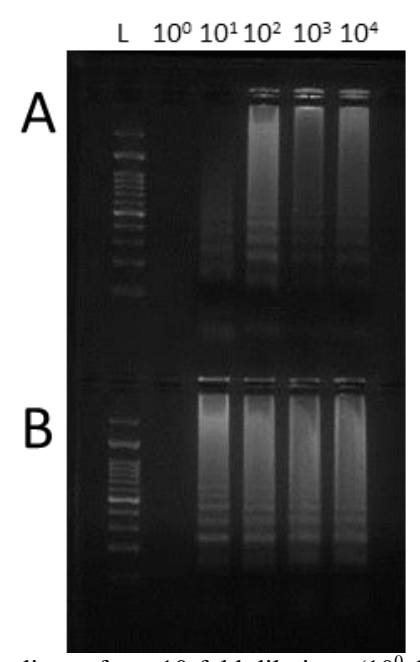

Figure 2 Amplicons from 10 -fold dilutions $\left(10^{0}-10^{4} \mathrm{GCs}\right)$ of hAdV40/41in nonextracted (A) and extracted (B) of fresh RTE lettuce samples. Lane L: 100bp ladder, Lane $1: 10^{0}$, Lane $2: 10^{1}$, Lane $3: 10^{2}$, Lane $4: 10^{3}$, Lane $4: 10^{4}$.

F species adenoviruses types 40 and 41 are the most recognized adenoviral types in suspected faecal-oral transmission through water and have been the prototypes for studies of gastroenteritis caused by adenoviruses, displaying characteristic gut tropism, in vivo (Leung and Brown, 2011). Types 40 and 41 are particularly difficult to isolate, due to the fact that they grow slowly in cell culture. Identification of adenovirus isolates can be accomplished by difficult and timeconsuming methods like neutralization with type-specific antisera or by DNA restriction analysis (Jothikumar et al., 2005). Therefore, these methods cannot be used for routine testing of clinical or food samples.

In the present study, the robustness of the LAMP assay for the analysis of food samples was shown by the detection of the target hAdV41 DNA in RTE food samples with smoother surface, like cherry tomatoes, green onions, and lettuce, without prior nucleic acids extraction. For instance, the detection without prior NA extraction procedure was proved to have a slight lower detection limit (approx. $1 \log$ ), compared to that of the samples tested after an NA step. On the other hand, in more complex food samples (strawberries, sour cherries), with porous surfaces, the target hAdV41 DNA was not detected without a prior nucleic acids extraction step. This can be a valuable tool for food companies and public health authorities interested in rapid and robust screening methods of food products.

Other researchers have used LAMP assays for the microbiological analysis of a variety of food products, like cantaloupe, lettuce, pepper, sprouts, tomato, milk, and chicken, for the rapid detection of a number of pathogens, like Salmonella spp, and Listeria monocytogenes, Shigella spp, Brucella and Escherichia coli (Shao et al., 2011, Song et al., 2012, Wang et al., 2011, Yang et al., 2015, Wu et al., 2015). Kou et al. (2014) developed a reverse transcription-loop-mediated isothermal amplification (RT-LAMP) assay for the detection of rotavirus in artificially seeded oysters. This is to the best of our knowledge the first report on the evaluation of hAdV40/41 specific LAMP assay for the virological analysis of food samples. The specificity has been tested successfully, and no crossreactivity with other targets was observed.

\section{CONCLUSION}

Our study underlined the usefulness of the developed LAMP assay for the virological analysis of fresh RTE foods. The greatest advantage of the present LAMP assay is the substantial reduction in required time (less than 60 minutes) compared to that required for PCR of Real-Time PCR. The developed LAMP assay is expected to provide a very robust, innovative, powerful, cheap and fast molecular diagnostic tool, for the food industry and the public health authorities.

Acknowledgements: This study was financially supported by "IKY FELLOWSHIPS OF EXCELLENCE FOR POSTGRADUATE STUDIES IN GREECE- SIEMENS PROGRAM".

\section{REFERENCES}

BÁNYAI K, KISFALI P, BOGDÁN A, MARTELLA V, MELEGH B ERDMAN D, SZUCS G. 2009. Adenovirus gastroenteritis in Hungary, 20032006. Eur. J. Clin. Microbiol. Infect. Dis. 28:997-999. http://dx.doi.org/10.1007/s10096-009-0722-8

D'SOUZA, D.H., SAIR, A., WILLIAMS, K., PAPAFRAGKOU, E., JEAN, J., MOORE, C., JAYKUS, L. 2006. Persistence of caliciviruses on enviromnental surfaces and their transfer to food. International Journal of Food Microbiology, 108, 84-91. http://dx.doi.org/10.1016/j.ijfoodmicro.2005.10.024
DUBOIS, E., HENNECHART, C., DEBOOSÈRE, N., MERLE, G., LEGEAY, O., BURGER, C., et al. 2006. Intra-laboratory validation of a concentration method adapted for the enumeration of infectious F-specific RNA coliphage, enterovirus, and hepatitis A virus from inoculated leaves of salad vegetables. International Journal of Food Microbiology, 108(2), 164-171. http://dx.doi.org/10.1016/j.j.ijfoodmicro.2005.11.007

FENG, H., BARBOSA-CÁNOVAS, G., WEISS, J. 2011. Ultrasound Technologies for Food and Bioprocessing, XII 666 http://dx.doi.org/10.1007/978-1-4419-7472-3

FONG TT, PHANIKUMAR MS, XAGORARAKI I, ROSE JB. 2010. Quantitative detection of human adenoviruses in wastewater and combined sewer overflows influencing a Michigan river. Appl. Environ. Microbiol. 76:715-723. http://dx.doi.org/10.1128/aem.01316-09

FRANCOIS P, TANGOMO M, HIBBS J, BONNETI EJ, BOEHME CC, NOTOMI T, PERKINS MD, SCHRENZEL J. 2011. Robustness of a loopmediated isothermal amplification reaction for diagnostic applications. FEMS Immunol Med Microbiol 62(1):41-48. http://dx.doi.org/10.1111/j.1574695x.2011.00785.x

GOGATE, P.R. 2007. Application of cavitational reactors for water disinfection: current status and path forward. J. Environ. Manage, 85, 801-815. http://dx.doi.org/10.1016/j.jenvman.2007.07.001

HARAMOTO E, KATAYAMA H, OGUMA K, OHGAKI S. 2007. Quantitative analysis of human enteric adenoviruses in aquatic environments. J. Appl. Microbiol. 103:2153-2159. http://dx.doi.org/10.1111/j.1365-2672.2007.03453.x HARAMOTO E, KITAJIMA M, KATAYAMA H, OHGAKI S. 2010. Real-time PCR detection of adenoviruses, polyomaviruses, and torque teno viruses in river water in Japan. Water Res. 44:1747-1752. http://dx.doi.org/10.1016/j.watres.2009.11.043

HEATON, J. C., and JONES, K. 2008. Microbial contamination of fruit and vegetables and the behaviour of enteropathogens in the phyllosphere: A review. Journal of Applied Microbiology, 104(3), 613626. http://dx.doi.org/10.1111/j.1365-2672.2007.03587.x

HERNROTH, B. E., CONDEN-HANSSON, A. C., REHNSTAM-HOLM, A. S., GIRONES, R., \& ALLARD, A. K. 2002. Environmental factors influencing human viral pathogens and their potential indicator organisms in the blue mussel, Mytilus edulis: The first Scandinavian report. Applied and Environmental Microbiology, 68(9), 4523-4533. http://dx.doi.org/10.1128/aem.68.9.45234533.2002

JOTHIKUMAR N, CROMEANS TL, HILL VR, LU X, SOBSEY MD, ERDMAN DD. 2005. Quantitative real-time PCR assays for detection of human adenoviruses and identification of serotypes 40 and 41. Appl. Environ. Microbiol. 71:3131-3136. http://dx.doi.org/10.1128/aem.71.6.3131-3136.2005

KOKKINOS, P., KOZYRA, I., LAZIC, S., BOUWKENGT, M., RUTJES S., WILLEMS, K., MOLONEY, R., DE RODA HUSMAN, A, M, KAUPKE, A., LEGAKI, E., D'AGOSTINO, M, COOK, N., RZEZUTKA, A., PETROVIC, T. VANTARAKIS, A. 2012. Harmonised Investigation of the Occurrence of Human Enteric Viruses in the Leafy Green Vegetable Supply Chain in Three European Countries. Food and environmental virology, 4(4), 179191. http://dx.doi.org/10.1007/s12560-012-9087-8

KOKKINOS P.A., ZIROS P.G., BELLOU M., VANTARAKIS A. 2014. LoopMediated Isothermal Amplification (LAMP) for the Detection of Salmonella in Food. Food Anal. Methods 7:512-526. http://dx.doi.org/10.1007/s12161-0139748-8

KOU X., FAN H., WU Q., XUE L., ZHANG J. 2014. Development and application of a loop-mediated isothermal amplification assay on rapid and sensitive detection of rotavirus in fecal samples and artificially seeded oysters. Food Control 41, 151-157. http://dx.doi.org/10.1016/j.foodcont.2014.01.013

LEE JI, LEE GC, CHUNG JY, HAN TH, LEE YK, KIM MS, LEE CH. 2012. Detection and molecular characterization of adenoviruses in Korean children hospitalized with acute gastroenteritis. Microbiol Immunol. 56(8):523-528. http://dx.doi.org/10.1111/j.1348-0421.2012.00469.x

LEUNG, T. K., and BROWN, M. 2011. Block in entry of enteric adenovirus type 41 in HEK293 cells. Virus Res. 156:54-63. http://dx.doi.org/10.1016/j.virusres.2010.12.018

MENG QS, GERBA CP. 1996. Comparative inactivation of enteric adenoviruses, poliovirus, and coliphage by ultraviolet irradiation. Water Res, 30:26658. http://dx.doi.org/10.1016/s0043-1354(96)00179-0

NOTOMI, T. -OKAYAMA, H. -MASUBUCHI, H. -YONEKAWA, T. WATANABE, K. -AMINO, N. -HASE, T. 2000. Loop-mediated isothermal amplification of DNA. Nucleic Acids Res., vol. 28, E63. http://dx.doi.org/10.1093/nar/28.12.e63

NUANUALSUWAN, S., CLIVER, D.O. 2003a. Capsid functions of inactivated human picornaviruses and feline calicivirus. Applied and Environmental Microbiology, 69, 350-357. http://dx.doi.org/10.1128/aem.69.1.350-357.2003 RODRÍGUEZ-LÁZARO D, COOK N, RUGGERI FM, SELLWOOD J, NASSER A, NASCIMENTO MS, D'AGOSTINO M, SANTOS R, SAIZ JC, RZEŻUTKA A, BOSCH A, GIRONÉS R, CARDUCCI A, MUSCILLO M, KOVAČ K, DIEZ-VALCARCE M, VANTARAKIS A, VON BONSDORFF CH, DE RODA HUSMAN AM, HERNÁNDEZ M, VAN DER POEL WH. 2012. Virus hazards from food, water and other contaminated environments. 
FEMS Microbiol. $\quad$ Rev. 36:786-814. $\quad$ http://dx.doi.org/10.1111/j.15746976.2011.00306.x

SDIRI-LOULIZI K, GHARBI-KHELIFI H, DE ROUGEMONT A, HASSINE M, CHOUCHANE S, SAKLY N, POTHIER P, GUÉDICHE MN, AOUNI M, AMBERT-BALAY K. 2009. Molecular epidemiology of human astrovirus and adenovirus serotypes 40/41 strains related to acute diarrhea in Tunisian children. J. Med. Virol. 81:1895-1902. http://dx.doi.org/10.1002/jmv.21586

SHAO Y., ZHU S., JIN C., CHEN F. 2011. Development of multiplex loopmediated isothermal amplification-RFLP (mLAMP-RFLP) to detect Salmonella spp. and Shigella spp. in milk. International Journal of Food Microbiology 148 (2011) 75-79. http://dx.doi.org/10.1016/j.ijfoodmicro.2011.05.004

SONG L., LI J., HOU S., LI X., CHEN S. 2012. Establishment of loop-mediated isothermal amplification (LAMP) for rapid detection of Brucella spp. and application to milk and blood samples. Journal of Microbiological Methods 90 292-297. http://dx.doi.org/10.1016/j.mimet.2012.05.024

VAN R., WUN C-C., O'RYAN M., MATSON D., JACKSON L., PICKERING L. 1992. Outbreaks of human enteric adenovirus types 40 and 41 in Houston day care centers. The Journal of Pediatrics 120,4,1. http://dx.doi.org/10.1016/s00223476(05)82477-1

WANG X., GENG F-Z., ZHANG X-Z., WANG Y., MA X-Y., SU X-D., TAN JX., ZHANG W. 2011. A loop-mediated isothermal amplification assay for rapid detection of Listeria monocytogenes. Journal of Food Safety 31, 546-552. http://dx.doi.org/10.1111/j.1745-4565.2011.00333.x

WU G.P., CHEN S.H. \& LEVIN R.E. 2015. Rapid real-time loop-mediated isothermal amplification combined with coated activated carbon for detection of low numbers of Salmonella enterica from lettuce without enrichment, Food Control. http://dx.doi.org/10.1016/j.foodcont.2015.03.008

YANG Q., WANG F., JONES K., MENG J., PRINYAWIWATKUL W., Ge B. 2015. Evaluation of loop-mediated isothermal amplification for the rapid, reliable, and robust detection of Salmonella in produce. Food Microbiology 46, 485-493. http://dx.doi.org/10.1016/j.fm.2014.09.011

ZIROS PG, KOKKINOS PA, ALLARD A, VANTARAKIS A. 2015

Development and Evaluation of a Loop-Mediated Isothermal Amplification Assay for the Detection of Adenovirus 40 and 41. Food Environ Virol. Feb 4 [Epub ahead of print] http://dx.doi.org/10.1007/s12560-015-9182-8 